\title{
Smoking, occupational exposure to rubber, and lung
}

\section{cancer}

\author{
ZUO-FENG ZHANG, ' SHUN-ZHANG YU, ${ }^{1}$ WAN-XIAN LI, ${ }^{1}$ B C K CHOI ${ }^{2}$ \\ From the Department of Epidemiology, ${ }^{1}$ School of Public Health, Shanghai Medical University, Shanghai, $P R$ \\ of China, and Occupational and Environmental Health Unit, ${ }^{2}$ University of Toronto, Toronto, Ontario, Canada
}

ABSTRACT A cohort of 1624 employees (957 men, 667 women) in a rubber factory in Shanghai have been followed up since 1972 and their 12 year mortality experience is presented. The relative risk ofo lung cancer for smokers was 8.5 for men and 11.4 for women and for rubber workers exposed to 3 curing agents or talc powder $3 \cdot 2$ for men and $4 \cdot 6$ for women.

Although many researchers have found that lung cancer is positively related to various jobs within the rubber industry, 't the effect of smoking on lung cancer and the interaction between smoking and exposure to rubber have not yet been reported. These questions have been explored by following up a cohort of 1624 rubber workers in Shanghai from 1 December 1972 to 30 November 1984.

\section{Material and methods}

\section{SUBJECTS}

A total of 1624 rubber workers (957 men, 667 women) in the Xuhui district of Shanghai who entered a screening programme for coronary heart disease in 1972 were included in the study. Thirty items such as smoking habit, drinking habit, and information on work history were obtained from the records of the screening programme. Records of subjects who took part in the screening programme were checked in 1982 and 1984 and the causes of death from death certificates classified by ICD-9 ${ }^{2}$. Eighty seven men and one woman were lost to follow up and the rate of follow up was $95 \%$ ( $91 \%$ for men, $99 \%$ for women).

\section{ANALYSIS}

Direct and indirect standardisation were used to calculate standard death rates and SMRs. ${ }^{3}$ The age distribution of the general population in Xuhui district with their specific cause of death from 1974 to 1984 was used as the standard. The data were stratified by smoking and jobs within the rubber plant. The Mantel-Haenszel method for follow up studies was used to analyse the effects of smoking and exposure to rubber on the risk of lung cancer. ${ }^{4}$ Additive and

Accepted 30 November 1987 multiplicative models were used to evaluate possible interaction effects. $^{5}$

The equation ${ }^{6}$ used to test the significance of $a_{c}^{-}$ difference of SMR from 100 is shown as follows:

$$
\chi^{2}=\frac{(\mid \text { Obs }-\operatorname{Exp} \mid-1 / 2)^{2}}{\operatorname{Exp}}, \mathrm{n}^{\prime}=1
$$

\section{Results}

Table 1 shows the 12 year mortality experience of 16 rubber workers (including both active and retiređ ) The death rate for all causes in rubber workers was lesso than that in the general population, whereas the mortality for all malignant neoplasms was close to that $\overrightarrow{0}$ in the general population. The SMR for lung cancer3 was the highest among the five main cancers. The? attributable risk (rate difference) for lung cancer in? rubber workers was $15 / 100000$ person-years for meno and 10/100 000 person-years for women, compared $\stackrel{\mathscr{}}{3}$ with the average death rate of lung cancer in Xuhuio district from 1974 to 1984 .

The death rate from lung cancer in rubber workersi with reference to the type of jobs was also analysed. The rubber workers were divided into five subgroups:응 (1) curing; (2) the inner tube of tyre; (3) raw material handling, weighing, mixing, extruding, and calender-은 ing; (4) component assembly and building; and (5) general service in the factory. The SMRs for lung. cancer for curing workers were 286 for both sexes (263N for men, 500 for women) and those for inner tyre tube స్ workers were 375 for both sexes ( 333 for men, 500 for women). The SMRs for lung cancer for curing and inner tube workers were higher than those for the other three groups (table 2).

The lung cancer death rate in rubber workers with reference to cigarette smoking was explored. The rate 
Table 1 Observed and expected number of deaths, SMR, and standard deaths rates (/100 000/year) in rubber workers in Shanghai by cause of death (1972-84)

\begin{tabular}{|c|c|c|c|c|c|c|c|c|c|c|c|c|c|}
\hline \multirow[b]{2}{*}{$I C D-9$} & \multirow[b]{2}{*}{ Cause of death } & \multicolumn{4}{|c|}{ Both sexes } & \multicolumn{4}{|l|}{ Men } & \multicolumn{4}{|c|}{ Women } \\
\hline & & Obs & $\operatorname{Exp}$ & $S M R$ & Rate & Obs & $\operatorname{Exp}$ & $S M R$ & Rate & Obs & $\operatorname{Exp}$ & $S M R$ & Rate \\
\hline $\begin{array}{l}001-999 \\
140-208 \\
162 \\
151\end{array}$ & $\begin{array}{l}\text { All causes } \\
\text { Neoplasms } \\
\text { Lung cancer } \\
\text { Cancer of }\end{array}$ & $\begin{array}{r}163 \\
66 \\
20\end{array}$ & $\begin{array}{r}191.6 \\
65.9 \\
15 \cdot 1\end{array}$ & $\begin{array}{r}85 \\
100 \\
133\end{array}$ & $\begin{array}{r}463 \\
157 \\
49\end{array}$ & $\begin{array}{r}117 \\
48 \\
16\end{array}$ & $\begin{array}{r}132 \cdot 9 \\
48 \cdot 2 \\
12 \cdot 1\end{array}$ & $\begin{array}{r}88 \\
100 \\
132\end{array}$ & $\begin{array}{r}472 \\
183 \\
60\end{array}$ & $\begin{array}{r}46 \\
18 \\
4\end{array}$ & $\begin{array}{r}58 \cdot 7 \\
17 \cdot 7 \\
3 \cdot 0\end{array}$ & $\begin{array}{r}78 \\
102 \\
132\end{array}$ & $\begin{array}{r}295 \\
106 \\
31\end{array}$ \\
\hline $\begin{array}{l}155 \\
153\end{array}$ & $\begin{array}{l}\text { stomach } \\
\text { Liver cancer } \\
\text { Cancer of }\end{array}$ & $\begin{array}{l}13 \\
10\end{array}$ & $\begin{array}{l}14 \cdot 0 \\
10 \cdot 1\end{array}$ & $\begin{array}{l}93 \\
99\end{array}$ & $\begin{array}{l}31 \\
23\end{array}$ & $\begin{array}{r}12 \\
8\end{array}$ & $\begin{array}{r}11 \cdot 1 \\
8 \cdot 2\end{array}$ & $\begin{array}{r}109 \\
98\end{array}$ & $\begin{array}{l}46 \\
32\end{array}$ & $\begin{array}{l}1 \\
2\end{array}$ & $\begin{array}{l}2.9 \\
1.9\end{array}$ & $\begin{array}{r}35 \\
105\end{array}$ & $\begin{array}{l}5 \\
9\end{array}$ \\
\hline 150 & $\begin{array}{l}\text { colon } \\
\text { Cancer of }\end{array}$ & 4 & $4 \cdot 6$ & 87 & 10 & 2 & $2 \cdot 8$ & 71 & 7 & 2 & $1 \cdot 4$ & 140 & 14 \\
\hline & oesophagus & 4 & $6 \cdot 2$ & 65 & 10 & 3 & $5 \cdot 0$ & 61 & 12 & 1 & $1 \cdot 2$ & 80 & 6 \\
\hline
\end{tabular}

Table 2 Observed and expected number of deaths and SMR of lung cancer of rubber workers in Shanghai from 1972 to 1984 by type of job

\begin{tabular}{|c|c|c|c|c|c|c|c|c|c|c|}
\hline \multirow{2}{*}{\multicolumn{2}{|c|}{ Type of job }} & \multicolumn{3}{|c|}{ Both sexes } & \multicolumn{3}{|l|}{ Men } & \multicolumn{3}{|c|}{ Women } \\
\hline & & $O b s$ & $\operatorname{Exp}$ & $S M R$ & Obs & $\operatorname{Exp}$ & $S M R$ & Obs & $\operatorname{Exp}$ & $S M R$ \\
\hline $\begin{array}{l}\text { (i) } \\
\text { (iii) } \\
\text { (iv) } \\
\text { (v) }\end{array}$ & $\begin{array}{l}\text { Curing } \\
\text { Inner tyre tube } \\
\text { Raw material handling, etc } \\
\text { Component assembly, etc } \\
\text { General service }\end{array}$ & $\begin{array}{l}6 \\
3 \\
3 \\
0 \\
8\end{array}$ & $\begin{array}{l}2 \cdot 1 \\
0.8 \\
2.9 \\
1.6 \\
7 \cdot 7\end{array}$ & $\begin{array}{l}286^{*} \\
375 \\
104 \\
0 \\
104\end{array}$ & $\begin{array}{l}5 \\
2 \\
3 \\
0 \\
6\end{array}$ & $\begin{array}{l}1 \cdot 9 \\
0 \cdot 6 \\
2 \cdot 7 \\
1 \cdot 1 \\
5 \cdot 8\end{array}$ & $\begin{array}{r}263 \\
333 \\
111 \\
0 \\
103\end{array}$ & $\begin{array}{l}1 \\
1 \\
0 \\
0 \\
2\end{array}$ & $\begin{array}{l}0 \cdot 2 \\
0 \cdot 2 \\
0 \cdot 2 \\
0.5 \\
1.9\end{array}$ & $\begin{array}{r}500 \\
500 \\
0 \\
0 \\
105\end{array}$ \\
\hline
\end{tabular}

${ }^{*} \mathrm{p}<0.05$.

of correspondence of the daily averages of cigarette smoking between 1972 and 1982 was $89 \%$ (table 3). The average proportions of smokers from 1972 to 1984 are $63 \%$ for male workers and $9 \%$ for female workers, which are higher than those in the general population in Xuhui district in 1983 (46\% for men, $5 \%$ for women, unpublished data). The excess proportions of smokers in the rubber factory compared with the general population were $39 \%$ for men, $69 \%$ for women, and $56 \%$ for both sexes; the excess proportions for lung cancer mortality were $32 \%$ for men, $50 \%$ for women, and $47 \%$ for both sexes (table 4 ). Although the proportion of smokers in male curing and inner tube workers was similar to that in other male workers $(63 \%$ compared with $64 \%$ for other workers), the proportion of heavy smokers ( $>10 /$ day) in curing and inner tube workers was $51 \%$, which was higher than that in other workers $(41 \%)$. The popula- tion attributable risk (PAR) of lung cancer in rubber workers who smoked was $83 \%$ for men and $48 \%$ for women (Shanghai: $81 \%$ for men, 19\% for women, unpublished data). The SMRs for lung cancer in heavy smokers of both sexes were the highest among the three smoking groups and were significantly raised. There was a dose response relation between average daily cigarette smoking and lung cancer SMR (table 5).

Rubber workers were divided into two groups: smokers and non-smokers and the crude relative risk of lung cancer for smokers was 8.7 for men and $\mathbf{1 0 . 3}$ for women. To calculate the Mantel-Haenszel relative risk (RR), these workers were divided into four subgroups by smoking habit (smoker and nonsmoker) and exposure to curing agents or inner tubes (yes or no). When the data were stratified by occupational exposure (to curing agents or inner

Table 3 Rate of correspondence* of daily average of smoking between 1972 and 1982 in rubber workers $\dagger$

\begin{tabular}{|c|c|c|c|c|c|}
\hline \multirow[b]{2}{*}{ Results of survey in 1972} & \multicolumn{4}{|c|}{ Results of survey in 1982 (No of subjects) } & \multirow[b]{2}{*}{ Total } \\
\hline & Non-smoking & $1-10$ cig/day & $11-20 \mathrm{cig} / \mathrm{day}$ & $>20 \mathrm{cig} / \mathrm{day}$ & \\
\hline $\begin{array}{l}\text { Non-smoking } \\
1-10 \mathrm{cig} / \mathrm{day} \\
11-20 \mathrm{cig} / \mathrm{day} \\
>20 \mathrm{cig} / \mathrm{day}\end{array}$ & $\begin{array}{r}750 \\
17 \\
8 \\
1\end{array}$ & $\begin{array}{r}37 \\
158 \\
14 \\
0\end{array}$ & $\begin{array}{r}3 \\
64 \\
332 \\
3\end{array}$ & $\begin{array}{r}1 \\
0 \\
17 \\
69\end{array}$ & $\begin{array}{r}791 \\
239 \\
371 \\
73\end{array}$ \\
\hline Total & 776 & 209 & 402 & 87 & 1474 \\
\hline
\end{tabular}

$*$ Rate of correspondence $(\%)=\frac{(750+158+332+69)}{1474} * 100=89 \%$

†Rate of follow up from 1972 to 1982 was $91 \%$. 
Table 4 Proportion of smokers and lung cancer mortality for rubber workers and general population of Xuhui district in Shanghai, 1972-84

\begin{tabular}{|c|c|c|c|c|c|c|c|c|}
\hline \multirow[b]{2}{*}{ Sex } & \multirow[b]{2}{*}{ Person-years } & \multirow[b]{2}{*}{$\begin{array}{l}\text { Person-years } \\
\text { of smoking }\end{array}$} & \multicolumn{2}{|c|}{$\begin{array}{l}\text { Proportion of smokers } \\
(\%)\end{array}$} & \multirow[b]{2}{*}{ Excess $(\%)$} & \multicolumn{2}{|c|}{$\begin{array}{l}\text { Mortality of lung cancer } \\
\text { (/100 000/year })\end{array}$} & \multirow[b]{2}{*}{ Excess $(\%)^{*}$} \\
\hline & & & $\begin{array}{l}\text { Rubber } \\
\text { workers }\end{array}$ & $\begin{array}{l}\text { Xuhui } \\
\text { areat }\end{array}$ & & $\begin{array}{l}\text { Rubber } \\
\text { workers }\end{array}$ & $\begin{array}{l}\text { Xuhui } \\
\text { areat }\end{array}$ & \\
\hline $\begin{array}{l}\text { Male } \\
\text { Female } \\
\text { Both sexes }\end{array}$ & $\begin{array}{r}10053 \\
7562 \\
17615\end{array}$ & $\begin{array}{r}6373 \cdot 5 \\
668 \cdot 0 \\
7041 \cdot 5\end{array}$ & $\begin{array}{r}63 \\
9 \\
40\end{array}$ & $\begin{array}{r}46 \\
5 \\
26\end{array}$ & $\begin{array}{l}39 \\
69 \\
56\end{array}$ & $\begin{array}{l}60 \\
31 \\
49\end{array}$ & $\begin{array}{l}46 \\
21 \\
33\end{array}$ & $\begin{array}{l}32 \\
50 \\
47\end{array}$ \\
\hline
\end{tabular}

*Equation for calculating excess proportion is as follows:

Excess proportion $(\%)=\frac{\text { rubber workers }- \text { Xuhui area }}{\text { Xuhui area }} \times 100$.

Xuhui area

†Proportion of smokers for Xuhui area was supplied by Xuhui Anti-Epidemic Station from a sample survey (10\% random sample from all population) in 1983 (unpublished data).

$\ddagger$ Mortality of lung cancer in Xuhui district 1974-84.

Table 5 Observed and expected number of deaths and SMR for lung cancer of rubber workers in Shanghai, 1972-84 by smoking and sex

\begin{tabular}{|c|c|c|c|c|c|c|c|c|c|}
\hline \multirow[b]{2}{*}{ Smoking status } & \multicolumn{3}{|c|}{ Both sexes } & \multicolumn{3}{|l|}{ Men } & \multicolumn{3}{|c|}{ Women } \\
\hline & $O b s$ & $\operatorname{Exp}$ & $S M R$ & $O b s$ & $\operatorname{Exp}$ & $S M R$ & $O b s$ & $E x p$ & $S M R$ \\
\hline $\begin{array}{l}\text { Non-smoking } \\
1-10 \mathrm{cig} / \mathrm{day} \\
>10 \mathrm{cig} / \mathrm{day}\end{array}$ & $\begin{array}{r}3 \\
1 \\
16\end{array}$ & $\begin{array}{l}6 \cdot 8 \\
1.9 \\
6 \cdot 4\end{array}$ & $\begin{array}{c}44 \\
53 \\
250^{* *}\end{array}$ & $\begin{array}{r}1 \\
1 \\
14\end{array}$ & $\begin{array}{l}4 \cdot 2 \\
1 \cdot 7 \\
6 \cdot 2\end{array}$ & $\begin{array}{c}24 \\
59 \\
226^{* *}\end{array}$ & $\begin{array}{l}2 \\
0 \\
2\end{array}$ & $\begin{array}{l}2 \cdot 6 \\
0 \cdot 2 \\
0 \cdot 2\end{array}$ & $\begin{array}{c}77 \\
0 \\
1018^{* *}\end{array}$ \\
\hline
\end{tabular}

${ }^{* *} \mathrm{p}<0.01$.

tubes), the RR of lung cancer for smokers was 8.5 for men $(1 \cdot 6-45 \cdot 2)$ and 11.4 for women $(2.4-53.5)$ (table 6).

The crude relative risk of lung cancer for occupational exposure (to curing agents or inner tubes) was 3.3 for men and 4.0 for women. When the effect of smoking was controlled (stratified by smoking habit), the RR for curing agent or inner tube exposure was $3 \cdot 2(1 \cdot 3-8 \cdot 2)$ for men and $4 \cdot 6(0 \cdot 8-27 \cdot 9)$ for women (table 7).

Additive and multiplicative models were used to evaluate the interaction between smoking and occupational exposure on lung cancer. Although the additive interaction term was $27 / 100000$ personyears, this was not statistically significant $(z=0.33, p$ $>0.05)$ and also a negative multiplicative interaction was found (table 8).

\section{Discussion}

In the present study an excess of lung cancer in Shanghai rubber workers was found. The age standard death rate of lung cancer for rubber workers was higher than that for the general population in the same district and during the same period, and the SMR for lung cancer was the highest among all causes of death. Mancuso noted an excess of lung cancer in Ohio rubber workers in 1949. ${ }^{7}$ Since then, there have been similar results in the United States, Britain, and Finland. ${ }^{8-10}$
Our study also shows a significant excess of deatis from lung cancer, particularly in those who worked 通 the curing workshop and a high but not statistical significant excess in those in the inner tube workshop. British investigators reported an excess of lung cancer among workers in tyre manufacture, particularly those engaged in the process of curing. ${ }^{9}$ Some epidemiologists in the United States also reported similar results in the curing workshop. ${ }^{11-13}$ The agent responsible for the excess of lung cancer is still obscure. In the curing workshop goods are sprayed with a solvent based lubricant before curing. The curing process itself generates condensed volatiles, vapours, and gases with unknown nature. In addition to curing agents, another possible cancer causing agent in the rubber industry is talc powder. In the inner tube workshop talc powder is used to dust the inner tyre tube. Kleinfeld and colleagues found that the proportional mortality rate for lung cancer in workers exposed to commercial talc dust was four times that of

Table 6 Stratifying on the degree of exposure to curing agents and inner tubes to assess the association between smoking and lung cancer

\begin{tabular}{lccc}
\hline Sex & $R R_{\text {crude }}$ & $R R$ & $95 \%$ CI for $R R$ \\
\hline Male & $8 \cdot 7^{*}$ & $8 \cdot 5^{*}$ & $1 \cdot 6-45 \cdot 2$ \\
Female & $10 \cdot 3^{* *}$ & $11 \cdot 4^{* *}$ & $2 \cdot 4-53 \cdot 5$ \\
\hline
\end{tabular}

*p < 0.05; **p < 0.01. 
Table 7 Stratifying on the degree of smoking to assess the association between exposure to curing agents and inner tubes and lung cancer

\begin{tabular}{llll}
\hline Sex & $R R_{\text {crnde }}$ & $R R$ & $95 \%$ CI for $R R$ \\
\hline Male & $3 \cdot 3^{*}$ & $3 \cdot 2^{*}$ & $1 \cdot 3-8 \cdot 2$ \\
Female & $4 \cdot 0$ & $4 \cdot 6$ & $0 \cdot 8-28 \cdot 0$ \\
\hline
\end{tabular}

*p $<0.05$.

the general population. ${ }^{14}$ Thomas and Stewart reported that workers exposed to talc had a significant 2.5fold excess risk of lung cancer. ${ }^{15}$ In our study the RR of lung cancer in workers exposed to curing and talc was 3.2 for men and 4.6 for women after the effect of smoking was controlled.

In the evaluation of lung cancer mortality the possible influence of cigarette smoking must be considered. In the present study the proportion of smokers among the rubber workers was higher than in the general population and the proportion of heavy smokers in curing and inner tyre tube workers was higher than in the other three groups, which was probably responsible for the excess of lung cancer in rubber workers, especially for workers in curing and inner tube workshop. There was a dose response relation between the SMR for lung cancer and daily averages of cigarette smoking. When the effect of exposure to rubber was controlled, the RR of lung cancer for smokers was more than eight and statistically significant. Doll and Hill reported that the relative risk of lung cancer in smokers was $12 \cdot 9 .^{16}$ The results of our research show a strong association between cigarette smoking and lung cancer and suggest that there is an urgent need to adopt effective measures against smoking in rubber workers.

In other industrial studies of lung cancer cigarette smoking was found to interact with certain occupational exposure. ${ }^{17}$ Selikoff and colleagues ${ }^{18}$ and Saracci ${ }^{19}$ analysed the epidemiological evidence on the asbestos-smoking interaction. Lednar and colleagues reported that smoking and rubber occupational exposure interact for pulmonary disability. ${ }^{20}$ In our data, although the additive interaction term was 27 / 100000 person-years, this was not statistically significant.

We thank Professor Fumin Shen and Professor Shouzhang Xue for many helpful discussions.

\section{References}

1 Heseltine E. International Agency for Research on Cancer monographs on the evaluation of the carcinogenic risk of chemicals to humans. Vol 28. The rubber industry. Lyon: IARC, 1982: 183-225.

2 World Health Organisation, eds. International classification of diseases. 1975 rev. Vol 1. Geneva: WHO, 1977.

3 Tsai SP, Wen CP. A review of methodological issues of the standardised mortality ratio (SMR) in occupational cohort studies. Int J Epidemiol 1986;15:8-21.

4 Kleinbaum DG, Kupper LL, Morgenstern H. Epidemiologic research, principles and quantitative methods. New York: Van Nostrand Reinhold, 1982:320-76.

5 Kleinbaum DG, Kupper LL, Morgenstern H. Epidemiologic research, principles and quantitative methods. New York: Van Nostrand Reinhold, 1982:403-18.

6 Monson RR. Occupational epidemiology. Boca Raton, Florida: CRC Press, 1980.

7 Mancuso TF. Occupational cancer survey in Ohio. Proceedings of the Public Health, Cancer Association of America 1949:56-70.

8 Monson RR, Fine LJ. Cancer mortality and morbidity among rubber workers. J Natl Cancer Inst 1978;61:1047-53.

9 Fox AJ, Lindars DC, Owen R. A survey of occupational cancer in the rubber and cable-making industries: results of five-year analysis, 1967-71. Br J Ind Med 1974;31:140-51.

10 Kilpikari I. Mortality among male rubber workers in Finland. Arch Environ Health 1982;37:295-9.

11 Monson RR, Nakano KK. Mortality among rubber workers. I. White male union employees in Akron, Ohio. Am J Epidemiol 1976;103:284-96.

12 Monson RR, Nakano KK. Mortality among rubber workers. II. Other employees. Am J Epidemiol 1976;103:297-303.

13 Andjelkovich D, Taulbee J, Symons M, Williams T. Mortality of rubber workers with reference to work experience. J Occup Med 1977;19:397-405.

14 Kleinfeld M, Messite J, Langer AM. A study of workers exposed to asbestiform minerals in commercial talc manufacture. Environ Res 1973;6:132-43.

15 Thomas TL, Stewart PA. Mortality from lung cancer and respiratory disease among pottery workers exposed to silica talc. Am J Epidemiol 1986;124:530.

16 Doll R, Hill AB. Lung cancer and other causes of death in relation to smoking: a second report on the mortality of British doctors. Br Med J 1956;ii:1071-81.

17 Berry G, Newhouse ML, Turok M. Combined effect of asbestos exposure and smoking on the mortality from lung cancer in factory workers. Lancet 1972;ii:476-9.

18 Selikoff IJ, Hammond EC, Churg J. Asbestos exposure, smoking and neoplasia. JAMA 1968;204:106-12.

19 Saracci R. Asbestos and lung cancer: an analysis of the epidemiological evidence on the asbestos-smoking interaction. Int J Cancer 1977;20:323-31.

20 Lednar WM, Tyroler HA, McMichael AJ, Shy CM. The occupational determinants of chronic disabling pulmonary disease in rubber workers. J Occup Med 1977;19:263-8.

Table 8 Analysis of interaction between smoking and occupational exposure to curing agents and inner tubes on deaths from lung cancer

\begin{tabular}{|c|c|c|c|c|c|c|}
\hline \multirow[b]{2}{*}{ Smoking status } & \multicolumn{2}{|c|}{$\begin{array}{l}\text { Age adjusted mortality rate } \\
\text { (/100 000/year) }\end{array}$} & \multicolumn{2}{|l|}{ Relative risk } & \multicolumn{2}{|c|}{$\begin{array}{l}\text { Attributable risk } \\
\text { (/100 000/year) }\end{array}$} \\
\hline & Non-exposure & Exposure* & Non-exposure & Exposure & Non-exposure & Exposure \\
\hline $\begin{array}{l}\text { Non-smoking } \\
\text { Smoking }\end{array}$ & $\begin{array}{r}6 \\
98\end{array}$ & $\begin{array}{r}50 \\
169\end{array}$ & $\begin{array}{r}1.0 \\
16 \cdot 3\end{array}$ & $\begin{array}{r}8 \cdot 3 \\
28 \cdot 2\end{array}$ & $\begin{array}{r}0 \\
92\end{array}$ & $\begin{array}{r}44 \\
163\end{array}$ \\
\hline
\end{tabular}

* $Z=0.33, p \geqslant 0.05$. 